\title{
GROUNDWATER LEVEL FORECASTING MODEL IN TROPICAL PEATLAND USING ARTIFICIAL NEURAL NETWORK
}

\author{
Imam Suprayogi \\ Civil Engineering Department, Faculty of Engineering \\ Riau of University, Indonesia \\ Ari Sandhyavitri \\ Civil Engineering Department Faculty of Engineering \\ Riau of University, Indonesia

\section{Nurdin} \\ Civil Engineering Department, Faculty of Engineering, \\ Riau University, Indonesia

\section{Joleha} \\ Civil Engineering Department Faculty of Engineering \\ Riau of University, Indonesia
}

\section{Wawan}

Agrotechnology Department, Faculty of Agriculture, Riau University, Indonesia

Azmeri

Civil Engineering Department, Faculty of Engineering,

Syiah Kuala University, Banda Aceh, Indonesia

\begin{abstract}
One of the key parameters in peat land management is water, which is expressed in the water level of peat land. The water level fluctuations of a peat land are closely related to the decomposition of the peat constituent material, its cover and hydrological conditions. When the water level drops, the peat decomposition increases and will release the carbon into the atmosphere. In addition, the condition of peat will be dry so that the area becomes prone to fire. The main purpose of the research is to develop a groundwater level forecasting model to monitor the dynamics of land water fluctuations in tropical peatland in order to comply with government regulation No. 57 of 2016 on the protection and management of peat ecosystems, especially the necessity to maintain water level at a rate of $40 \mathrm{~cm}$. The method of research approach used is using ANN as one branch of soft computing. The location of research on
\end{abstract}


peatland of PT Meskom Pulau Bengkalis, Riau province. Data that is used to build a model of groundwater level forecasting in tropical peatland sourced from Hobo Water Logger measuring device that record water table in 2014. The main results of the research proved that the implementation of a groundwater level forecasting model on the tropical peatlands in Bengkalis using the ANN method approach for the next day ( $t$ $+24)$ has a very strong classification tested using statistical parameters coefficient of correlation $(R)$ and Mean Square Error (MSE) respectively 0.995929 and 0.0003026 so that the model can be applied on tropical peatlands.

Keywords: Model, forecasting, groundwater level, tropical peatland, Artificial Neural Network (ANN).

Cite this Article: Imam Suprayogi, Ari Sandhyavitri, Nurdin, Joleha, Wawan, Azmeri, Groundwater Level Forecasting Model in Tropical Peatland Using Artificial Neural Network. International Journal of Civil Engineering and Technology, 11(2), 2020, 68-78.

https://iaeme.com/Home/issue/IJCIET?Volume $=11 \&$ Issue $=2$

\section{INTRODUCTION}

Norman Borlaug, who once won the Nobel Prize, stated that the land of sour was one of the last of the agricultural fronts. It is not excessive to assume that tropical peatlands are also included in this category. From the world's total peatland area of 423,825,000 ha, 38,317,000 ha is located in the tropical zone. About $52.4 \%$ (20,073,000 ha) of all tropical peatland are found in Indonesia, so Indonesia ranks 4th in the total area of global peatland. It is then said by Radjagukguk (2007) that Peatland has a very different character with mineral land. Geomorphological types of Ombrogen peatlands are generally dominant in Indonesia dome shaped and formed between two rivers flow. Tropical peatlands are fragile ecosystems, which are highly vulnerable to human disorder, and tropical peat soils have distinctive properties that differ greatly from the mineral soils in general.

Tropical peatlands, especially those in Indonesia, are characterized as having a distinctive biodiversity advantage with a rich diversity of flora and fauna that is a valuable genetic resource (germ plasma). The peatland is also inhabited by a variety of fish species that can be consumed, and overgrown by a variety of high economic value forest trees such as Ramin (Gonystylus bancanus), Meranti (Shorea sp) and its hydrological functions, which can store very large quantities of fresh water. One hectare of $2 \mathrm{~m}$ thick tropical peatland is estimated to store water as much as 1.2 million $\mathrm{m}^{3}$. Thus, the peatland plays an important role for freshwater storage for the surrounding area and as well as the environmental buffer of drought and flood hazards. Besides having advantages, the fundamental problem faced by tropical peat is fragile, because with land clearing and reclamation will undergo a subsidence, acceleration, and the risk of the irreversible shrinkage, and is prone to erosion hazard. The flow rate subsidence can reach $40-50 \mathrm{~cm}$ in the first few years, and after that it slows to $2-5$ $\mathrm{cm}$ per year and its practical nature is not renewable, it takes 5000-10,000 years to its formation until it reaches the maximum thickness About $20 \mathrm{~m}$, so the estimate of its easing rate is $1 \mathrm{~cm} / 5$ years, under forest vegetation. Also the peat is flammable and continuously undergo the process of decomposition biodegradable (Radjagukguk, 2001)

Furthermore, the important event noted, sourced from the Government of the Republic of Indonesia, 2.6 million hectares of land and forest has been burned between June and October 2015, equivalent to the size four and a half fold island of Bali. The world Bank estimates that fires in Indonesia in 2015 cost at least Rp 221 trillion (16.1 US dollars) or equivalent to 1.9 percent of the GDP in 2015. 
The loss value of $\mathrm{Rp} 221$ trillion is more than doubling the cost for the reconstruction of Aceh tsunami. The amount is beyond the calculation of health, education, germ plasm, carbon emissions and other losses. Losses are higher compared to similar events in 1997 where fires of forest and land (Karhutla) harms the state to Rp 60 trillion. As it is known, during this period there were Karhutla simultaneously in Jambi, Riau, South Sumatera, South Kalimantan, West Kalimantan and East Kalimantan. The cause of the burning accident, the opening of new land by some communities, poor management of the peat swamp ecosystem, the long dry season due to El Nino and the weak supervision (World Bank Group, 2016).

Highlighted by the Head of Data and Information Center and Public Relations of the National Disaster Management Agency (BNPB) Sutopo Purwo Nugroho in the press conference on Disaster Relief Evaluation 2015 and catastrophic prediction 2016 stated that the loss is equal to 1.5 percent of national gross domestic product, Karhutla means the pace of development. The impact of forest fires, continued Sutopo, 24 persons dead, more than 600 thousand people contracted upper respiratory tract infections (ISPA), 60 million people were exposed to smoke and as many as 2.61 million hectares of forests and burned land. Of 2.61 million hectares of burnt land, there are 33 percent of the peat land area of 869,754 hectares. While the fire in mineral land area of 1,741,657 hectares or 67 percent.

Sourced from the Agency for Assessment and Aplication of Technology (BPPT), Ministry of Environment and Forestry and analysis of staff of the World Bank from July to October 2015 stated that the land area burned in Riau province approximately 139 million hectares or approximately 5\% of the total of 2611 million hectares of forest land burned in seven provinces in Indonesia. Estimated loss and damage caused by forest fires and haze, in JuneOctober 2015 in Riau province approximately 1,373 million US dollars of total losses in seven provinces in Indonesia, approximately 16,124 million US dollar (World Bank Group, 2016).

\subsection{Importance of Groundwater Level Forecasting in Tropical Peatland}

One of the key parameters in Peatland management is water, which is expressed in the groundwater level at peatland. The ground water level fluctuation of a peat land is closely related to the material decomposition of peat formation, its cover and hydrological conditions. In addition to external factors such as the dynamics of rainfall and the intensity of sun radiation. When the ground water level down, the peat decomposition increases and will release the carbon into the atmosphere. In addition, the condition of peat will be dry and serve as ' ready-to-burn or burned ' materials so that the area becomes prone to fire. (Sulaiman, et al., 2017). In an effort to prevent tropical peatland fires in Indonesia as described above, the Government of Indonesia has issued government regulation No. 71 of 2014 Jo Government regulation No. 57 year 2016 on protection and Management of peat ecosystems, particularly the necessity of maintaining TMA at a rate of $40 \mathrm{~cm}$ (Sulaiman, et al, 2017). As an illustration of the successful cultivation of oil palm in the oil palm plantations of United Plantations Berhad in Teluk Intan, Malaysia, the coating and drying of peat top layer can be suppressed by maintaining the depth of ground water in of drained lines of $50-75 \mathrm{~cm}$ below the surface (Singh, 1991). The maintenance of groundwater level also prevents the oxidation of the pyrite material, which may be found under peat layers.

\subsection{Implementation Model Softcomputing}

In the last decade, the softcomputing model as a branch of artificial intelligence is introduced as a forecasting tool such as knowledge based system, expert system, fuzzy logic, artificial neural network and genetic algorithm (Purnomo, 2004), and other. Still according to Purnomo (2004) basic selection of softcomputing model as a tool in the modeling of systems, 
softcomputing modeling is very advantage to work on an non linear system that is quite difficult mathematical models, as well as the flexibility of the parameters used is an obstacle to other tools.

Adamowski, et.all (2011) has been conducting research to estimate groundwater level at St.Remi Station Watershed Quebec, New York using the ANN and ARIMA method approaches. The main research results stated that the ANN method has the best accuracy in the period of testing periods for groundwater forecasting for the next month when compared with the ARIMA method tested using statistical parameters the correlation coefficient (R) with a respectively 0752 and 0566 and the value of Root Mean Square Error (RMSE) is respectively 0817 and 4,137. Furthermore Affandi, et.al (2007) has done research to predict groundwater level in the well observation in Urawa 1 and Urawa 2, Japan using ANN algorithm Levenberg - Marquardt (ANN-LM), ANN algorithm Radial Basis Function (ANN$\mathrm{RBF}$ ) and Adaptive Neuro Fuzzy Inference System (ANFIS). The results proved that the three methods have the accuracy of groundwater level prediction with the best accuracy for one day ahead. It was found that the value of the third prediction method with the measuring result (observed) amounted to $85 \%$ in the range of \pm 0.2 meters and proved that three algorithms ANN-LM, ANN-RBF and ANFIS have the same predicted results. Furthermore Daliakopoulus et. all (2005) had done research for the groundwater level estimate in a 398 $\mathrm{km}^{2}$ basin in the Southern part of Crete Island in Greece using a seven-algorithm approach to the method ANN. Results of the primary research results stated that the ANN method of the Levenberg-Marquardt algorithm (LM) has the best accuracy advantage for the forecast of groundwater level forecasting for the next eighteen months $\left(\mathrm{H}_{\mathrm{t}+18}\right)$ with a model architecture consisting of 20 inputs, 3 layers hidden (hidden layer) and 1 output.

Referring to the success of previous research related to the implementation of Artificial Intelligence branches in groundwater engineering using Softcomputing model which one of its components is ANN which has a specific advantage (generic) for pattern data recognition. The main purpose of the research is to develop a high forecasting model of ground water advance on tropical peatland PT. Meskom, Bengkalis, Bengkalis Regency, Riau Province to monitor the dynamics of ground water fluctuations in the appropriate tropical peatland with the Government regulation of the Republic of Indonesia No 57 year 2016 on the protection and management of peat ecosystems, especially the necessity to maintain water level at level $40 \mathrm{~cm}$ to keep water governance maintained from potential threat hazard Forest fires and land. Research location is done on the peatland of PT Meskom Pulau Bengkalis, Riau Province.

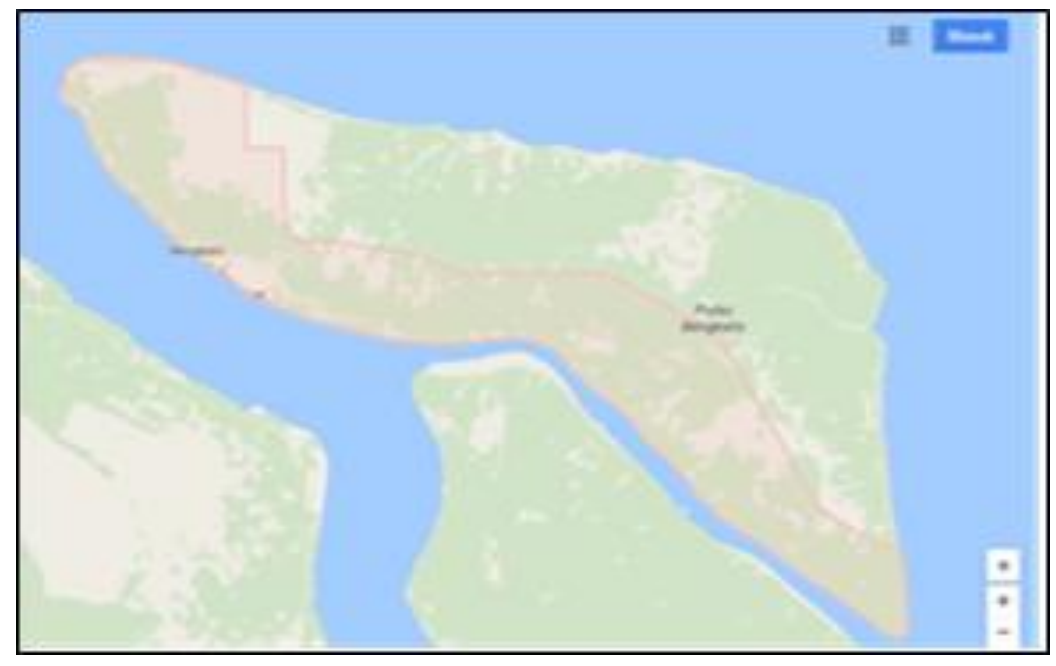

Figure 1 Location of groundwater level forecast in tropical peatland points the PT Meskom Pulau Bengkalis, Riau Province. 


\section{DATA USED AND GROUNDWATER LEVEL MODELING}

Data collection In this research is sourced from data water table level in the form of logger or numeric obtained from the HOBOware tools. The data obtained from this HOBO tool is the data of the groundwater level parameters, which is presented in the form of Excel format in 2014. The stage analysis of groundwater level forecasting on tropical peatland using the ANN method approach is presented as shown in Figure 2 below:
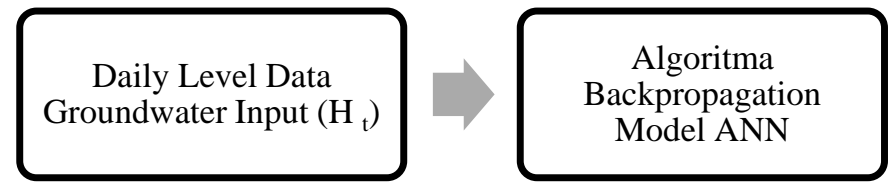

The Output Model ANN of the Groundwater Level for the needs of forecasting the next day $\left(\mathrm{H}_{\mathrm{t}+24}\right)$

Figure 2.Stages of analysis groundwater level forecasting in tropical peatland using the method ANN

Step solution groundwater level forecasting model in tropical peatland using ANN Back propagation algorithm

- The preparation of data from groundwater level in peat land sourced from data of groundwater level using HOBO Water Level Logger tool, at PT Meskom in the region of Bengkalis, Riau province which has been presented in the form of Excel format year 2014 for the need of training process $70 \%$, testing $30 \%$ and simulation process of the model $100 \%$

- The process of training data by conducting data input as much as 70\% from 20 August to 2014 until 25 November 2014 to the program Toolbox Matlab 7.0 to get a fit ANN model of back propagation algorithm.

- The step of the data training process begins with the statistical parameters test coefficient of correlation (R) to get the best value of R in ANN's six model parameters i.e. neurons, transfer function, epochs, max fail, learning rate, and momentum. After getting the best correlation level result then the training data is completed.

- The process of testing the data by input the groundwater level data on peatland as much as 30\% data from 26 November 2014 until 23 December 2014 by entering the parameters of training process results to the program the Toolbox Matlab 7.0 by doing a trial and errors to get the best correlation rate result in the data testing process

- Process of data simulation by input data groundwater level in peatland as much as $100 \%$ from 20 August 2014 until 23 December 2014 by entering the parameters of training process results to the program Toolbox Matlab 7.0 to get results The best level of correlation at the stage of data simulation process

- The final process with the forecasting process of groundwater level on peatland after ANN model is done after a series of training process, testing and simulation of finished model. The forecasting result of the ANN model (output) is then compared to the measurement result value. ANN model conformance and measurement results using statistical parameter test coefficient of correlation (R) and Mean Square Error (MSE) to get the best correlation rate result at forecasting process

The precision evaluation of the model is conducted by comparing the high groundwater level on peat land of the model ANN simulation and the data of the available measurement results. Models can be said to be precise if there is a high correlation value between simulated and measured result data. One of the statistical parameter tests is the correlation coefficient $(\mathrm{R})$ is the price indicating the magnitude of the relation between the value of observation and the simulation value. The model precision test is done using the correlation coefficient $(\mathrm{R})$ which follows the equation as follows: 


$$
R=\frac{\sum_{i=1}^{i=N} Q_{o b s} Q_{m}}{\left[\sum_{i=1}^{i=N}\left(Q_{o b s i}-\bar{Q}_{o b s}\right) \Delta^{i} \sum_{i=1}^{i=N}\left(Q_{m i}-\overline{Q_{m}}\right)^{2}\right]^{1 / 2}}
$$

With Qobs is a discharge observation $\left(\mathrm{m}^{3} / \mathrm{s}\right), \mathrm{Q}_{\mathrm{m}}$ is the discharge model $\left(\mathrm{m}^{3} / \mathrm{s}\right)$ and the $\mathrm{N}$ is the number of samples.

Classification of the strength of degree of relationship based on result coefficient value correlation between simulation result of Model and measurement result data. For R equals 0 has a relationship degree no correlation, $0<\mathrm{R}<0.25$ has a very weak degree of correlation relationship, $0.25<\mathrm{R}<0.50$ has a degree of insufficient correlation relationship, $0.50<\mathrm{R}<$ 0.75 has a strong correlation degree, $0.75<\mathrm{R}<0.99$ degrees correlation relationship is very strong and $\mathrm{R}$ equals 1 degree of perfect correlation relationship (De Farias, 2010).

\section{RESULTS AND DISCUSSION}

Design of network architecture with ANN structure adapted to the format of training data, i.e. network with one input consisting of high measurement result data time series groundwater level of HOBOware tool at time $\mathrm{t}\left(\mathrm{H}_{\mathrm{t}}\right)$ and one output is high ground water level at the time to $\mathrm{t}+24\left(\mathrm{H}_{\mathrm{t}+24}\right)$. Further mathematically can be formulated in equation 1 form as follows.

$$
\mathrm{H}_{\mathrm{t}+24}=\mathrm{f}\left(\mathrm{H}_{\mathrm{t}}\right)
$$

The next step is to set up the configuration schema model forecasting groundwater level data time series which is expected to be able to predict groundwater level for one day ahead $\left(\mathrm{H}_{\mathrm{t}+24}\right)$. There are two very important stages in the forecasting process using the ANN structure backpropagation algorithm that is the process of training data and the testing process data (Suprayogi, 2009). Applications with the ANN structure require data training and data testing. Both contain an input/output pattern. If training data was used to train the structure of ANN, data testing was used to assess the performance of the ANN structure.

There are three stages in building a high forecasting model of groundwater level on the peatland of PT Meskom Pulau Bengkalis, Riau Province using the ANN approach of backpropagation algorithm which is stages of training process, testing process, and model validation process. Use of data at the stage of training, testing and validation of models to build ANN models of backpropagation algorithms compiled like Table 1 below

Table 1. Data composition for process Training, Testing and Validation Model ANN

\begin{tabular}{|l|l|c|c|c|c|}
\hline Input Data & \multicolumn{1}{|c|}{ Process } & $\begin{array}{c}\text { Start Data } \\
\text { (input) }\end{array}$ & $\begin{array}{c}\text { End Data } \\
\text { (input) }\end{array}$ & $\begin{array}{c}\text { Start Data } \\
\text { (target) }\end{array}$ & $\begin{array}{c}\text { EndData } \\
\text { (target) }\end{array}$ \\
\hline \multirow{2}{*}{$\begin{array}{l}\text { Groundwat } \\
\text { er Level at } \\
\text { time t }\left(\mathrm{H}_{\mathrm{t}}\right)\end{array}$} & Training $(70 \%)$ & $20 / 8 / 2014$ & $25 / 11 / 2014$ & $21 / 8 / 2014$ & $26 / 11 / 2014$ \\
\cline { 2 - 6 } & Testing $(30 \%)$ & $26 / 11 / 2014$ & $23 / 12 / 2014$ & $27 / 11 / 2014$ & $24 / 12 / 2014$ \\
\cline { 2 - 6 } & $\begin{array}{l}\text { Validation } \\
\text { (100\%) }\end{array}$ & $20 / 8 / 2014$ & $23 / 12 / 2014$ & $21 / 8 / 2014$ & $24 / 12 / 2014$ \\
\hline
\end{tabular}

\subsection{Training Model}

The process of training model is used to train the structure of ANN. In the stage of training model using the method ANN backpropagation algorithm first done test process statistical parameters coefficient correlation $(\mathrm{R})$ to get the best $\mathrm{R}$ value from the six model ANN parameters are neurons, transfer function, epochs, Max fail, learning rate, and momentum. The test result values of the next six parameters are presented as in Table 2 below. 
Groundwater Level Forecasting Model in Tropical Peatland Using Artificial Neural Network

Table 2. Best parameter value of Model ANN Backpropagation algorithm

\begin{tabular}{|c|c|c|c|c|c|c|c|}
\hline \multirow{2}{*}{ Parameter } & \multirow{2}{*}{ neurons } & \multicolumn{2}{|c|}{$\begin{array}{c}\text { Transfer } \\
\text { function }\end{array}$} & \multicolumn{5}{c|}{ Parameter } \\
\cline { 3 - 8 } & & layer 1 & $\begin{array}{c}\text { layer } \\
\mathbf{2}\end{array}$ & epochs & max fail & $\begin{array}{c}\text { learning } \\
\text { rate }\end{array}$ & momentum \\
\hline & 10 & purelin & tansig & 1000 & 1000 & 0,5 & 0,9 \\
\hline
\end{tabular}

Sources : Results Running MATLAB Program

The stastitical parameter test value of each ANN model parameter uses the best coefficient of correlation ( $\mathrm{R}$ ) value on each parameter of the model which is presented as shown in Figure 3 below

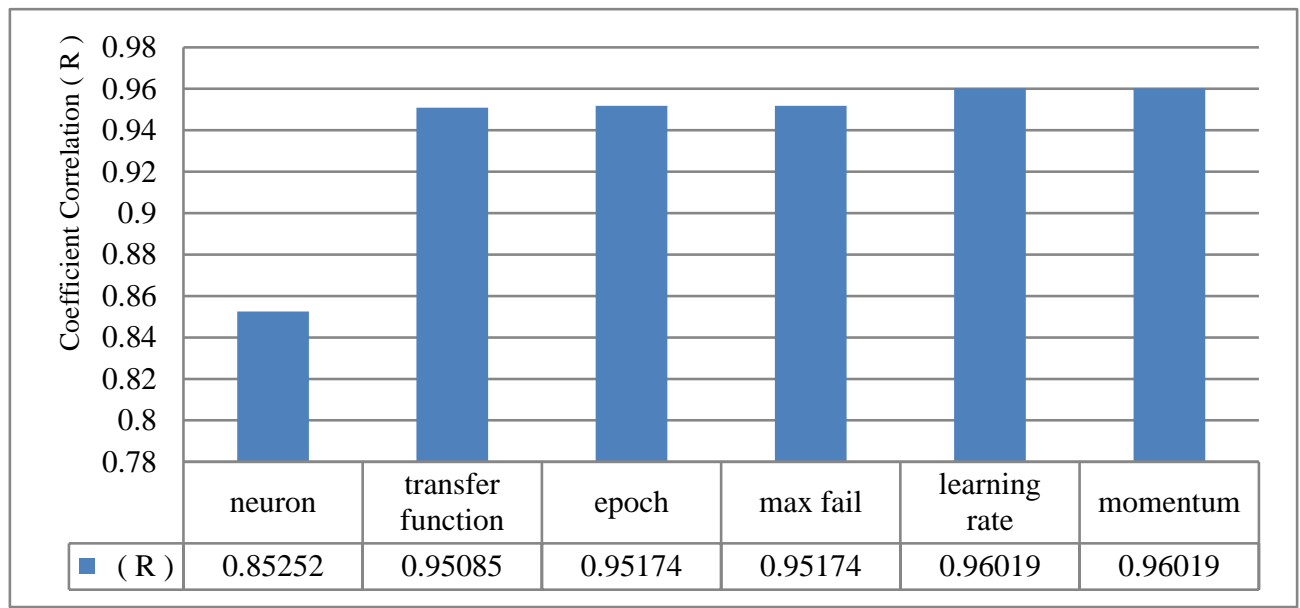

Sources : Results Running MATLAB Program

Figure 3. Coefficient value best correlation of six model ANN parameters

Once obtained a coefficient value of best correlation of six ANN model parameters then the value of the model parameter can be set with the number neurons 10, the transfer function on layer 1 using the Pureline and layer 2 using Tansig, the number of epoch 1000, the number of max file 1000, learning rate number 0.5 , and momentum number 0.9 as input model at the level of training data using the program Toolbox Matlab 7.0 with data allocation as much as 70\% from 20 August 2014 until 25 December 2014 as presented as shown in Figure 4 below.

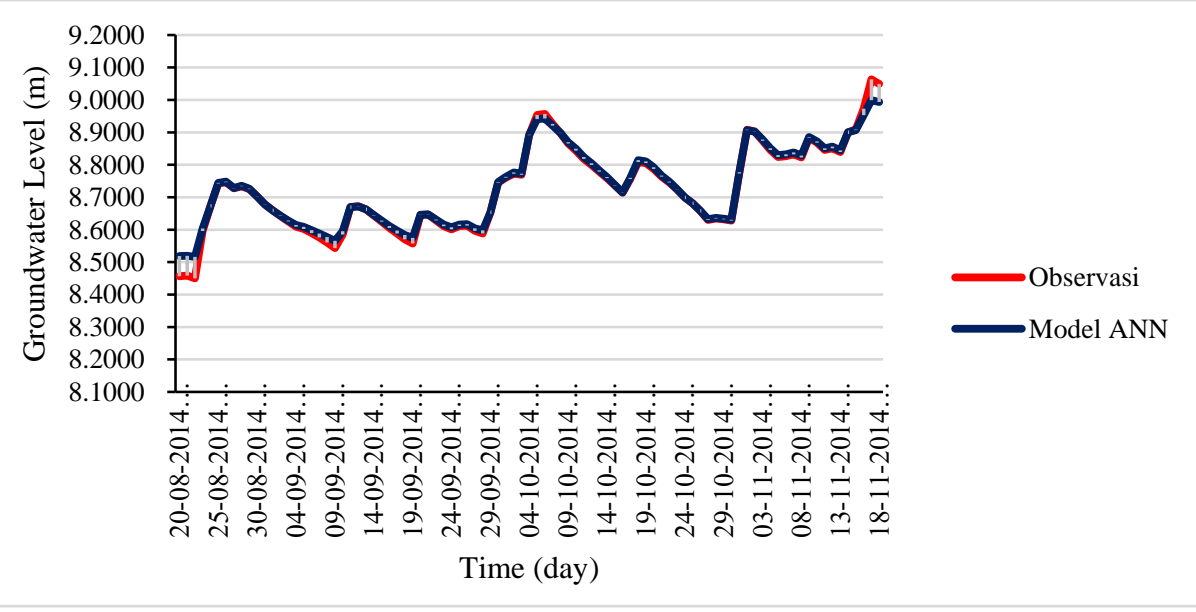

Figure 4. Description of the model ANN training results on the observation value 
Referring from Figure 4 above, it will be obtained statistical parameter test value in data training process between ANN model and observation data in field has very strong classification with correlation coefficient value of 0.96019

\subsection{Testing Model}

After the process of training data that aims to train the structure of ANN then the next step is done the process of testing data using the architecture of ANN model consisting of one input layer, one hidden layer with 10 nodes and one output Layer, which is used to assess the performance of the ANN structure. Results of data testing analysis with data input 26 November 2014 until 23 December 2014 (30\% data other than the data used traning process). As for the more results are presented as shown in Figure 5 below

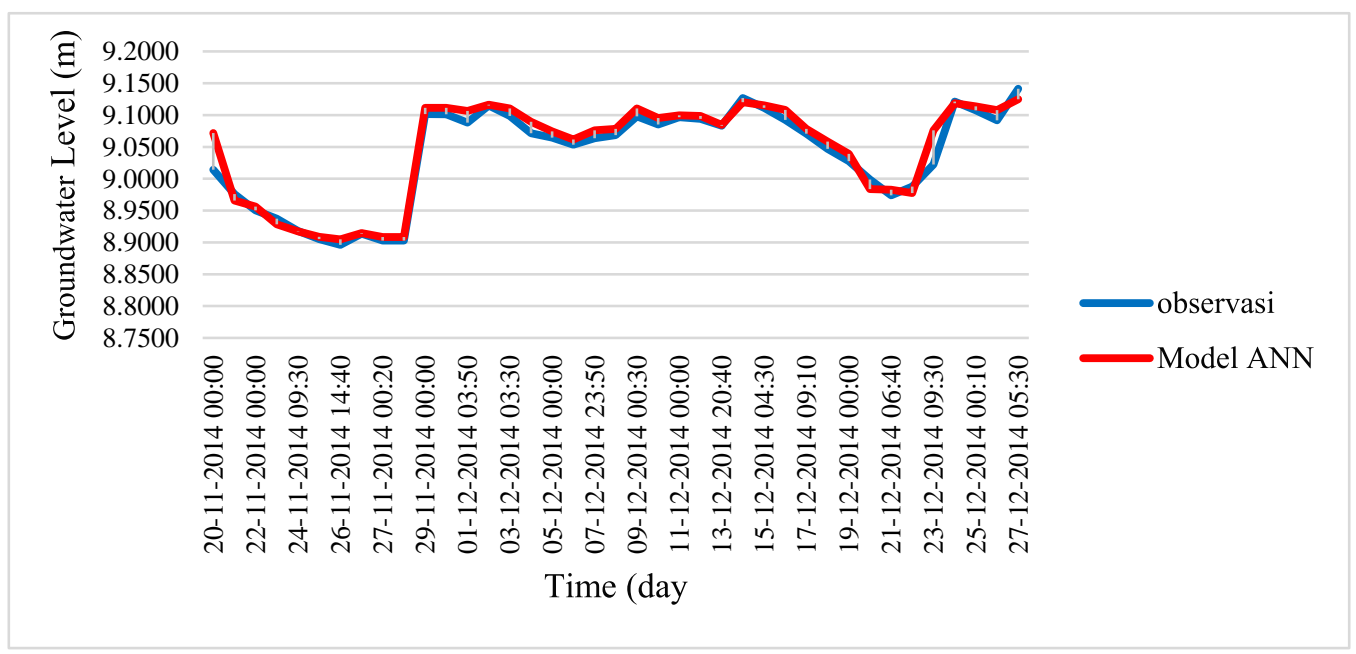

Figure 5. Description of the model ANN testing results on the observation value

Referring from Figure 5 above, it will be obtained statistical parameter test value in data testing process between ANN model and observation data in field has very strong classification with correlation coefficient value of 0.937246

\subsection{Validate Model}

The model validation according to Refsgaard (2000) is an attempt to validate the use of the model to obtain forecasts that the water resource manager can use. Model validation stage is the last process after the training process and the testing phase. Results of the analysis of data validation with data input 20 August 2014 until 23 December 2014 using the program the Tools Matlab 7.0 then acquired graph of relations between the Model ANN with the results of observations presented as shown in Figure 6 below.

Referring from Figure 6 above, states that the correlation coefficient value of 0.97456 indicates between the results of the ANN model validation stage with the observation value of the degree classification of the very strong relationship.For further description of statistical parameter test result using best $\mathrm{R}$ value in training process, testing process and validation process for forecasting groundwater level on tropical peatland for 24 The next hour $\left(\mathrm{H}_{\mathrm{t}+24}\right)$ uses the model ANN backpropagation algorithm which is presented as shown in table 2 


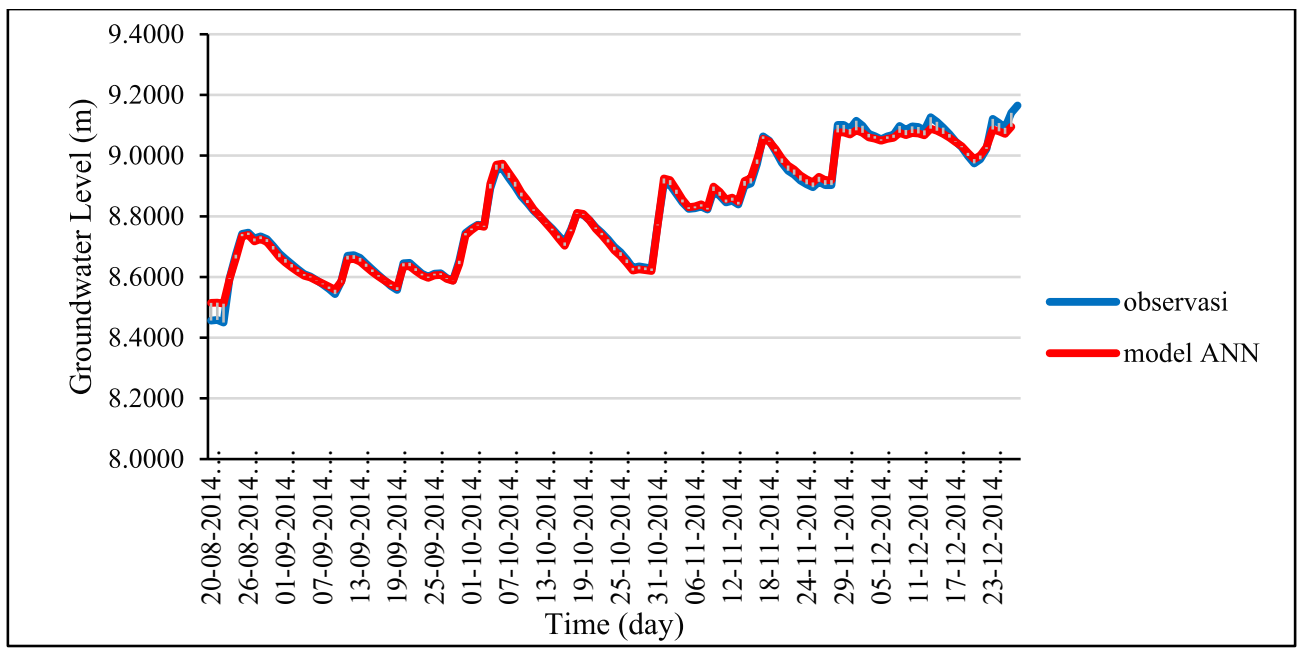

Figure 6. Description of the model ANN validation results on the observation value

\subsection{The Result of Ground water Level forecasting}

The recommendation of the use of models is the final process after the training, testing and validation of the model, which describe the performance of the groundwater level forecasting model using ANN for one day ahead $\left(\mathrm{H}_{\mathrm{t}+24}\right)$ with the result data measurements in the field, which are further presented as shown in Figure 7 below.

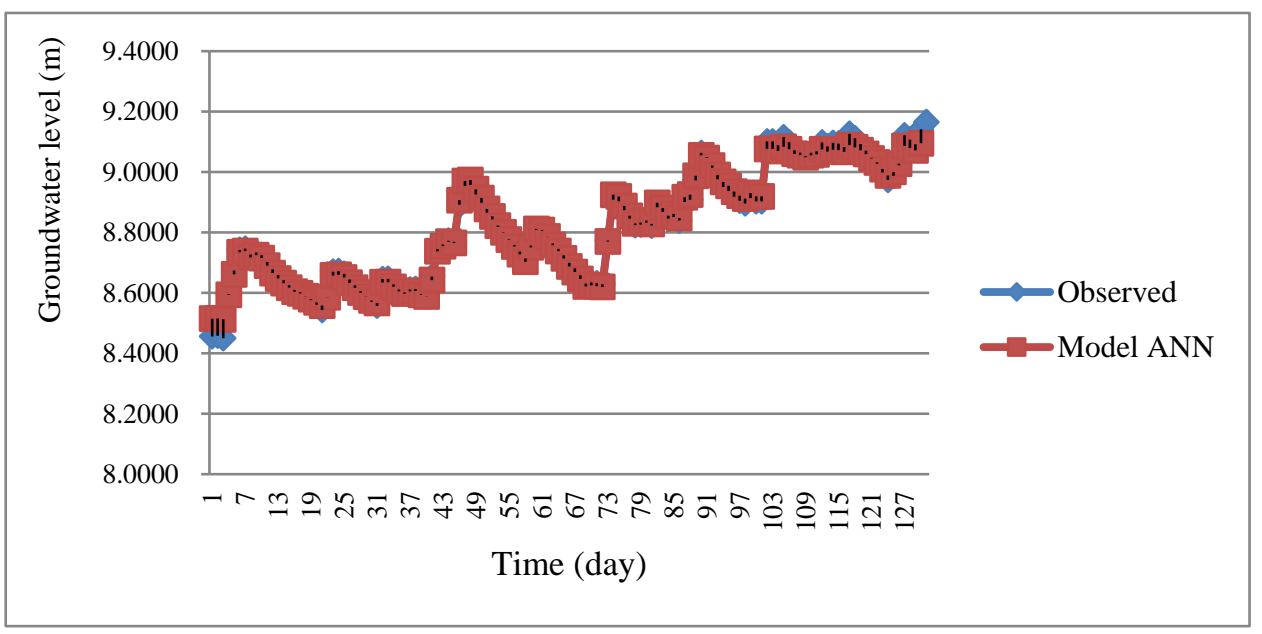

Figure 7. Description of the results between the ANN model for the groundwater level forecasting for one day ahead $\left(\mathrm{H}_{\mathrm{t}+24}\right)$ and measurements in the field

Referring Figure 7 above, the results of the research proved the use of the model ANN backpropagation algorithm as one of the softcomputing branches that have advantages on recognized pattern data resulted in high forecasting accuracy of groundwater level on tropical peatland in PT MESKOM Pulau Bengkalis Regency of Bengkalis for one day ahead $\left(\mathrm{H}_{\mathrm{t}+24}\right)$ has a degree of very strong relationship with the value of coefficient of correlation (R) of 0.996 and value Mean Square Error (MSE) of 0.0003 with the classification of the degree of relationship is very strong, so that the model can be used as needs prediction to monitoring fluctuations dynamics of groundwater level, especially the necessity to maintain high water advance at $40 \mathrm{~cm}$ as efforts to threat the dangers of forest fires and land. 


\section{CONCLUSION}

Based on the results and the discussion described above, it can be concluded as follows the development of the ground water level forecasting model on tropical peatlands in PT. MESKOM PulauBengkalis Regency Bengkalis has a network architecture of 1 input layer. 1 hidden layer with 10 neurons and 1 layer output with stages of training, testing and validation the ANN model contributes to the value of the correlation coefficient $(\mathrm{R})$ is a respectively $0.96019,0.93724$ and 0.97456 degrees of very strong relationships and ANN Model can be applied to the need for groundwater level forecasting on tropical peatland at PT. MESKOM Pulau Bengkalis in Bengkalis Regency for one day ahead $\left(\mathrm{H}_{\mathrm{t}+24}\right)$ with the value of coefficient of correlation $(\mathrm{R})$ of 0.996 has a strong classification of relations degrees, so that the model can be a necessity of forecasting monitoring fluctuations of groundwater level, especially the necessity to maintain high water level at a rate of $40 \mathrm{~cm}$ as an early preventive effort threat of forest fires and land.

\section{ACKNOWLEDGEMENTS}

The author thanked the joint research team between Miyazaki University and the Department of Civil Engineering, Faculty of Engineering, University of Riau that has granted the use of groundwater level data on peatland PT. Meskom Pulau Bengkalis, Regency of Bengkalis and Fajri Rahmatullah, ST. for the help of operation of MATLAB 7.0 Toolbox Program to support this research.

\section{REFERENCES}

[1] Adamowski, J. and Chan, H. F. A wavelet neural network conjunction model for ground water level forecasting, Journal of Hydrology, 407, 2011, pp. 28-40

[2] Affandi, A. K. Daily groundwater level fluctuation forecasting using soft computing technique, Journal Nature and Science, 5(2),2007, pp. 1 - 11.

[3] De Farias, C. A. S., Alves, L. M., Santos, C. A. G. and Suzuki, K. An ANN based approach to modeling sediment yield : A case study Semi Arid Area of Brazil : Proceding of the ICCE Symposium Held at Warsaw Poland in Life Science -SGGW Poland, 14 - 18 June 2010 IAHS Publish 557, 2010.

[4] Daliakopoulos, L. N., Coulibalya, P. and Tsanis, I. K. Groundwater level forecasting using artificial neural networks. Journal of Hydrology, 309, 2005, pp. 229-240.

[5] Fausset, L. Fundamentals of Neural Networks, Architectures, Algorithms, and Applications, New Jersey: Prentice Hall, 1996.

[6] Glauber, A. J., Moyer, S., Adriani, M. and Gunawan, I. Indonesia Sustainable Landscape Knowledge Report : Disadvantages of Economic Fires and Forest Fire Crisis 2015, World Bank Group Republic of Indonesia, 2016.

[7] Purnomo, M. H. Soft Computing Technology: The Prospect and Its Implementation on Medical and Electric Engineering, Surabaya: Speech Inaugural to Professorship In Artificial Intelligence Science on Faculty of Industrial Technology (IT), Sepuluh Nopember Institute of Technology (ITS), 2004.

[8] Pratikto, W.A. Application for Modeling in Marine Engineering, Surabaya: Speech Inaugural to Professorship Field of Numerical Applications and Fluid Mechanics at Department of Marine Engineering, Faculty of Marine Engineering, Sepuluh Nopember Institute of Technology (ITS), 1999.

[9] Radjagukduk, B. The Problem Perspectives and Conception of Tropical Peatland Management for Sustainable Agriculture, Jogyakarta : Speech Inaugural to Professorship 
Field of Soil Chemistry Science at Faculty of Agriculture, Gadjah Mada of University, 2001 .

[10] Refsgaard, J. C. Towards a Formal Approach to Calibration and Validation of Models Using Spatial Data, Dalam R. Grayson and G. Blöschl. Spatial Patterns in Catchment Hydrology: Observations and Modelling, Britain: Cambridge University Press, 2000, pp. $329-354$.

[11] Singh, G. Oil palm cultivation on peat soil in United Plantation Berhad, Kuching: Tropical Peat International Symposium on Tropical Peatland, Post Tour Guide II, 1991, pp 6-12.

[12] Sulaiman, A., Nirmalasari, E. N. and Saad, A. Technical Guide for Peat Land Groundwater Level Monitoring Telemetry System, Jakarta : Peatland Restoration of Agency (BRG), Republic of Indonesia, 2017.

[13] Suprayogi, I. Model of Salt Intrusion Forecasting in Estuary Using Softcomputing, Dissertation, Surabaya: Management and Water Resource Engineering, Department of Civil Engineering, Faculty of Civil Engineering, Environmental and Earthquake, Sepuluh Nopember Institute of Technology (ITS), 2009.

[14] Iriawan, N. Stokhastic Simulation Development in Data Driven Computing Statistics, Speeches Inaugural to Professorship in the Field of Computational Statistics and Stochastic Processes in the Statistics, Surabaya: Department Faculty of Mathematics and Natural Sciences, Sepuluh Nopember Institute of Technology (ITS), 2005. 